\title{
DIFFERENCE IN BLOOD FUNCTION TOXICITY BETWEEN STADIUM IIB-IIIB SQUAMOUS CELL CERVICAL CANCER PATIENTS WITH PACLITAXEL CISPLATIN AND PACLITAXEL CARBOPLATIN CHEMOTHERAPY AT SANGLAH HOSPITAL, DENPASAR
}

\author{
INDRAYATHI PA ${ }^{1}$, NOVIYANI R ${ }^{2 *}$, NIRURI R $^{2}$, BUDIANA ING ${ }^{3}$, TUNAS $\mathrm{K}^{4}$ \\ ${ }^{1}$ Department of Public Health, Faculty of Medicine, Udayana University, Bali, Indonesia. ${ }^{2}$ Department of Pharmacy, Faculty of \\ Mathematics and Sciences, Udayana University, Bali, Indonesia. ${ }^{3}$ Department of Obstetrics and Gynecology, Faculty of Medicine, Udayana \\ University, Bali, Indonesia. ${ }^{4}$ Department of Public Health, Faculty of Health, Science and Technology, Dhyana Pura University, Bali, \\ Indonesia. Email: rini.noviyani@gmail.com
}

Received: 21 August 2017, Revised and Accepted: 11 October 2017

\begin{abstract}
Objective: Paclitaxel cisplatin and paclitaxel carboplatin were chemotherapy regimens used for cervical cancer treatments at Sanglah Hospital, Denpasar. They came with hematologic toxicity side effects. This could be monitored from hemoglobin, thrombocyte, and leukocyte parameter. Data that compared the toxicity of these two regimens were still limited at Sanglah Hospital, Denpasar. Therefore, it was necessary to conduct a research about the difference in blood function toxicity between patients who underwent paclitaxel cisplatin chemotherapy and those who underwent paclitaxel carboplatin chemotherapy based on those three parameters.
\end{abstract}

Methods: This was a prospective observational research with consecutive sampling, inclusion, and exclusion criteria. It was carried out from January to August 2016 at Sanglah Hospital, Denpasar. Patients were categorized into two groups based on their chemotherapy regimens. Next, blood samples from both groups were tested for its hemoglobin, thrombocyte, and leukocyte level before and after chemotherapy. The data underwent normality test using either Shapiro-Wilk or Mann-Whitney test with SPSS.

Results: There were 17 patients who fulfilled the inclusion criteria. The result showed a decrease in hemoglobin, thrombocyte, as well as leukocyte values in patients who underwent paclitaxel cisplatin and paclitaxel carboplatin chemotherapy.

Conclusion: The decrease of both hemoglobin and leukocyte level was not meaningful in both groups ( $>0.05)$. Meanwhile, the decrease of thrombocyte level was meaningful in both groups $(* \mathrm{p}<0.05)$ in which patients who belong to paclitaxel carboplatin chemotherapy group showed a higher decrease of thrombocyte values.

Keywords: Chemotherapy, Cervical cancer, Paclitaxel cisplatin, Paclitaxel carboplatin, Hemoglobin, Thrombocyte, Leukocyte.

(c) 2018 The Authors. Published by Innovare Academic Sciences Pvt Ltd. This is an open access article under the CC BY license (http://creativecommons. org/licenses/by/4. 0/) DOI: http://dx.doi.org/10.22159/ajpcr.2018.v11i1.22125

\section{INTRODUCTION}

Cervical cancer is among the highest prevalent illnesses in Indonesia. In 2013, of 347,792 cancer patients, cervical cancer was the most prominent one among women with 98,692 patients, defeating breast cancer with 61,682 patients [1]. In 2015, it was recorded that there were 200 cervical cancer patients of 261 gynecological cancer patients. Meanwhile, in 2016 (January - August), there were as many as 195 cervical cancer patients of 236 gynecological cancer patients at Sanglah Hospital. These 2015-2016 data show that there was an increase in the number of cervical cancer patients, particularly at Sanglah Hospital, Denpasar. As a result, it is necessary to conduct further research about methods for treating cervical cancer.

One method to address cervical cancer is chemotherapy. Chemotherapy is a kind of treatment that uses cytotoxic medicines to kill cancerous cells [2], and they are given in either single or combination. Combined chemotherapies are seen as more effective than single chemotherapies due to their better response as well as their ability to prolong patients' life expectancies [3]. The most common combined regimens used for cervical cancer treatments at Sanglah Hospital, Denpasar, are paclitaxel cisplatin and paclitaxel carboplatin that are the first lines of cervical cancer chemotherapies [4]. Research by Moore et al. shows that paclitaxel cisplatin combination provides better response and increases life quality. This is also the case for paclitaxel carboplatin combination [5]. It is the most recommended as well as the most usable combined medicines in cervical cancer therapies, particularly for those in advanced stadiums [6]. Chemotherapies with paclitaxel carboplatin combined regimens are known to have the same efficacy with paclitaxel cisplatin combined regimens. That is why these two combined regimens become the standard treatment options for metastasis or recurring cervical cancer patients [7].

On the other side, chemotherapies can trigger numerous side effects and complications as well [8]. The use of cisplatin can cause blood toxicity such as leukopenia, thrombocytopenia, and anemia. The use of carboplatin can also cause blood toxicity with the main side effects which include myelosuppression or spinal cord depression that will result in low blood cells production leading to anemia, thrombocytopenia, and leukopenia [9]. Another contributing factor for toxicity is the amount of chemotherapy cycles underwent by patients. The more chemotherapy cycles they have, the higher the toxicity effect will be. This claim is supported by a research from Smith et al. that states how lung cancer patients who underwent 6 cycles of chemotherapy have higher blood toxicity effect compared to those who underwent 3 cycles of chemotherapy of mitomycin, vinblastine, and cisplatin [10]. Chemotherapies with both paclitaxel cisplatin and paclitaxel carboplatin regimens at Sanglah Hospital, Denpasar, are conducted for 3 until 6 cycles with the interval of 3 weeks for every cycle. Thus, the risks of toxicity effect in patients are also higher. Therefore, it is essential to carry out researches that monitor the toxicity effects of chemotherapies in blood functions. 
In addition, researches that compare the toxicity effects of blood functions as the result of the use of paclitaxel cisplatin and paclitaxel carboplatin for combined chemotherapies in stadium IIB-IIIB squamous cell cervical cancer patients at Sanglah Hospital, Denpasar, are rare. Hence, researches about this topic are necessary.

\section{METHODS}

This was a prospective observational research located at Sanglah Hospital, Denpasar, Bali. The research began after getting approval from the Litbang Ethical Commission of UNUD Medicine Faculty/Sanglah Hospital, Denpasar (Ethical Clearance number:1036/UN.14.2/ Litbang/2016). Samples were collected from January to August 2016 at Sanglah Hospital, Denpasar Obstetric and Gynecology (OBGYN) polyclinic. Samples were selected with consecutive sampling. The inclusion criteria were stadium IIB-IIIB squamous cell cervical cancer new patients, patients who were willing to fill in the informed consent, and those who consent for their laboratories data (hemoglobin, thrombocyte, and leukocyte) to be collected, as well as patients who were able to go through all series of chemotherapies from Cycle I until Cycle VI. The exclusion criteria were patients whose development could not be followed because of specific reasons such as death and lost to follow-up. Then, the selected patients were categorized into two groups that include patients who underwent paclitaxel cisplatin regimen chemotherapy and patients who underwent paclitaxel carboplatin regimen chemotherapy. Every patient in each group was observed from the moment the patients underwent first chemotherapy cycle until sixth chemotherapy cycle with the interval of 3 weeks within each cycle. Patients' blood was collected from before they underwent the first chemotherapy and after they underwent the sixth chemotherapy. It was then checked for its hemoglobin, thrombocyte, and leukocyte level at the laboratory of Sanglah Hospital, Denpasar, Bali, Pathological clinic. The data from each patient were then collected and analyzed statistically with SPSS after they underwent normality test with Shapiro-Wilk test. Data with normal distribution were further analyzed with independent t test. Data with abnormal distribution were further analyzed with Mann-Whitney test with $95 \%$ confidence level $\left({ }^{*} \mathrm{p}=0.05\right)$. The collected data would be meaningful if the value of $* p<0.05$.

\section{RESULTS}

\section{Patients' characteristics}

The number of samples collected from January to August 2016 was 17 patients. They consisted of two groups with 7 patients belong to paclitaxel cisplatin group and 10 patients belong to paclitaxel carboplatin group. All of them fulfilled the criteria to be the samples in this research. All of the patients' characteristics could be observed in the following Table 1.

Difference in hematologic toxicity between cervical cancer patients with paclitaxel cisplatin chemotherapy and paclitaxel carboplatin chemotherapy

Normality test by Shapiro-Wilk produced data with abnormal distribution, so Mann-Whitney test was conducted to analyze data from hemoglobin, thrombocyte, and leukocyte level before chemotherapy I and after chemotherapy VI from patients of both groups. The Mann-Whitney test result was shown in the following Table 2.

\section{DISCUSSION}

\section{Patients' characteristics}

All samples in this research were married with a diverse range of age. The number of patients belongs to the group of 36-45 years was 4 people in paclitaxel cisplatin group and 6 people in paclitaxel carboplatin group. Meanwhile, the number of patients belongs to the group of 46-65 years was 3 people for paclitaxel cisplatin group and 4 people for paclitaxel carboplatin group. From Table 1, it could be seen that women who got married within the age range of 15-25 years old were 7 patients for paclitaxel cisplatin group and 8 patients for paclitaxel carboplatin group. Meanwhile, there were 2 patients from paclitaxel carboplatin
Table 1: Data of squamous cell cervical cancer patients' characteristics

\begin{tabular}{|c|c|c|}
\hline $\begin{array}{l}\text { Patients } \\
\text { characteristics }\end{array}$ & $\begin{array}{l}\text { Paclitaxel } \\
\text { cisplatin } n=7 \text { (\%) }\end{array}$ & $\begin{array}{l}\text { Paclitaxel carboplatin } \\
\mathrm{n}=10(\%)\end{array}$ \\
\hline \multicolumn{3}{|l|}{ Age } \\
\hline $36-45$ & $4(57.14)$ & $6(60)$ \\
\hline $46-65$ & $3(42.86)$ & $4(40)$ \\
\hline \multicolumn{3}{|l|}{ Marital status } \\
\hline Married & $7(100)$ & $10(100)$ \\
\hline Not married & $0(0)$ & $0(0)$ \\
\hline \multicolumn{3}{|l|}{ Age of marriage } \\
\hline $15-20$ years & $4(57.14)$ & $4(40)$ \\
\hline $21-26$ years & $3(42.86)$ & $4(40)$ \\
\hline$>26$ & $0(0)$ & $2(20)$ \\
\hline \multicolumn{3}{|l|}{ Educational level } \\
\hline $\begin{array}{l}\text { No formal } \\
\text { education }\end{array}$ & $1(14.29)$ & $3(30)$ \\
\hline Elementary school & $4(57.14)$ & $2(20)$ \\
\hline Middle school & $1(14.29)$ & $2(20)$ \\
\hline High school & $1(14.29)$ & $2(20)$ \\
\hline Bachelor & $0(0)$ & $1(10)$ \\
\hline \multicolumn{3}{|l|}{ Occupational status } \\
\hline Entrepreneur & $0(0)$ & $6(60)$ \\
\hline Farmer & $1(14.29)$ & $2(20)$ \\
\hline Homemaker & $1(14.29)$ & $1(10)$ \\
\hline Civil servant & $0(0)$ & $1(10)$ \\
\hline Housemaid & $1(14.29)$ & $0(0)$ \\
\hline Private employee & $2(28.57)$ & $0(0)$ \\
\hline Merchant & $2(28.57)$ & $0(0)$ \\
\hline \multicolumn{3}{|l|}{ Area of origin } \\
\hline Bali & $3(42.86)$ & $8(80)$ \\
\hline Sulawesi & $1(14.29)$ & $0(0)$ \\
\hline East Lombok, NTB & $2(28.57)$ & $2(20)$ \\
\hline East Java & $1(14.29)$ & $0(0)$ \\
\hline \multicolumn{3}{|l|}{ Stadium of disease } \\
\hline IIB & $0(0)$ & $2(20)$ \\
\hline IIIB & $7(100)$ & $8(80)$ \\
\hline
\end{tabular}

n: Number of patients

group who got married at the age of beyond 26 years old. This is in line with a literature that stated how cervical cancer is one of the diseases transmitted through sexual intercourse [11]. This means that one of the risk factors for cervical cancer is women who have got married [12]. This is also supported by a research that states that if the first sexual intercourse was done before the age of 20, the risk of contracting cervical cancer will be higher since human papilloma virus (HPV) infection is commonly occurring within the age range of 18-30 years old, which is a few years after the intercourse took place [13]. HPV types 16 and 18 among women with cervical cancer in Aleppo, Syria, were detected in approximately $74 \%$ of cervical cancer patients. This indicates prophylactic vaccines against HPV type 16 and 18 is necessary to prevent cervical cancer among Syrian women [14].

Based on Table 1, it was concluded that the most commonly found cervical cancer stadium was stadium IIIB with 7 patients from paclitaxel cisplatin group and 8 patients from paclitaxel carboplatin group. On the other hand, there were only 2 people from paclitaxel carboplatin group with stadium IIB. This research shows how most cervical cancer cases are diagnosed during advanced stadiums. It is due to how there are no obvious symptoms during early stadiums of cervical cancer. The symptoms such as vaginal abnormal bleeding or odorous vagina can only be detected during advanced stadiums, and this is why this cancer is often known as the silent killer [15]. The most common educational level among patients was elementary school with 4 patients from paclitaxel cisplatin group and 8 patients from paclitaxel carboplatin group. Most patients from paclitaxel cisplatin group were working as merchants, and private employees with 2 patients each and 8 patients from paclitaxel carboplatin group were working as entrepreneurs. Looking from the area of origin, most patients were mostly from 
Table 2: Comparison result of hemoglobin, thrombocyte, and leukocyte decrease before chemotherapy Cycle I and after chemotherapy Cycle VI between patients from paclitaxel cisplatin regimen group and patients from paclitaxel carboplatin regimen group with MannWhitney test

\begin{tabular}{llll}
\hline Parameter blood function & \multicolumn{2}{l}{ Mean \pm SD } & \\
\cline { 2 - 4 } & Paclitaxel cisplatin regimen $\mathbf{n = 7}$ & Paclitaxel carboplatin regimen $\mathbf{n = 1 0}$ & $\mathbf{p}$ \\
\hline Hemoglobin $(\mathrm{g} / \mathrm{dL})$ & $1.01 \pm 1.17$ & $1.01 \pm 1.11$ & 0.999 \\
Thrombocyte $\left(10^{3} / \mu \mathrm{L}\right)$ & $71.19 \pm 114.39$ & $229.75 \pm 132.66$ & $0.022^{*}$ \\
Leukocyte $\left(10^{3} / \mu \mathrm{L}\right)$ & $5.47 \pm 5.49$ & $10.5 \pm 8.83$ & 0.202 \\
\hline
\end{tabular}

Bali with 3 patients for paclitaxel cisplatin group and 8 patients for paclitaxel carboplatin group.

\section{Difference in blood function toxicity}

Hematological system was most commonly affected by chemotherapy agents because of non-selective action of chemotherapeutic drugs. A study by Antony et al. reported 61 (37.88\%) adverse drug reaction of chemotherapeutic drugs in hematological system. The chemotherapeutic drugs target the rapidly dividing cells, such as bone marrow and tumor cells, which cause bone marrow suppression leading to anemia, leukopenia, neutropenia, and thrombocytopenia [16]. In this research, monitoring of chemotherapy toxicity was conducted toward blood function that includes hemoglobin, thrombocyte, and leukocyte. Based on Table 2, it could be seen that there was a not meaningful decrease of the hemoglobin values from before chemotherapy Cycle I and after chemotherapy Cycle VI after they underwent Mann-Whitney test. It was marked with the value ${ }^{*} \mathrm{p}=0.999$, in which the decrease of hemoglobin level was 1.01 in both groups of patients with paclitaxel cisplatin regimen and patients with paclitaxel carboplatin regimen. This decrease was the side effect of cisplatin regimen chemotherapy that often led to anemia. Carboplatin is also known to cause the myelosuppressive effect that lowering the production of blood cells in the spinal cord. This will lead to the decrease of red blood cells that can trigger anemia [9]. The most common hematologic toxicity occurred from the use of paclitaxel and cisplatin chemotherapy is anemia. This will be the case with 30 of 43 cervical cancer patients [17]. According to the research of Mell et al., cisplatin intake of 4 until 6 chemothrapy cycles would trigger acute anemia with the percentage of $48.6 \%$ in cervical cancer patients [18]. Another research by Umayahara et al. showed that paclitaxel cisplatin regimen intake would cause Grade 2 anemia in 26 patients (38.24\%) of 68 cervical cancer patients [19]. Meanwhile, paclitaxel carboplatin regimen intake for 6 cycles in cervical cancer patients would cause Grade 3 anemia with the percentage of $48.3 \%$ [20]. Not to mention, a research by El-Deen et al. also showed that 6 of 50 ovarium cancer patients who took paclitaxel carboplatin regimen suffered from severe anemia and 32 patients suffered from mild anemia [21]. Anemia will cause our bodies to be lacking in nutrients and oxygen that will lead to organ damage such as heart if it happens continuously [22].

In this research, toxicity monitoring toward thrombocyte values was also conducted for squamous cell cervical cancer patients from both paclitaxel cisplatin and paclitaxel carboplatin chemotherapy groups before chemotherapy Cycle I and after chemotherapy Cycle VI. The result showed a decrease in thrombocyte level after chemotherapy. The decrease of thrombocyte level from paclitaxel carboplatin group was $229.75 \pm 132.66 \times 10^{3} / \mu \mathrm{L}$ which was higher than paclitaxel cisplatin group with $71.19 \pm 114.39 \times 10^{3} / \mu \mathrm{L}$ with the value of $* \mathrm{p}<0.05$ was 0.022 . This means that there was a meaningful decrease of thrombocyre values in squamous cell cervical cancer patients from before chemotherapy I and after chemotherapy VI with either paclitaxel cisplatin regimen or paclitaxel carboplatin regimen. This decrease was a side effect of cisplatin regimen chemotherapy that could cause mild thrombocytopenia [9]. However, this effect will rarely happen [23]. Carboplatin is known to be able to increase the risk of thrombocytopenia since it can make that the thrombocyte level becomes $<100 \times 10^{3} / \mu \mathrm{L}[24,25]$. According to the research of Mell et al., cisplatin intake of 4 until 6 chemotherapy cycles has the percentage of $37.8 \%$ of causing thrombocytopenia in cervical cancer patients [18]. Another research by Umayahara et al. showed that paclitaxel cisplatin regimen intake would cause Grade 1 thrombocytopenia in 12 patients $(17.65 \%)$ of 68 cervical cancer patients [19]. Meanwhile, paclitaxel carboplatin chemotherapy would also cause thrombocytopenia in 58\% of ovarium cancer patients [26]. Research by Rosell et al. also showed that paclitaxel carboplatin regimen would cause a higher risk of thrombocytopenia for as much as $27 \%$ compared to $13 \%$ in non-small-cell-lung cancer patients with paclitaxel cisplatin regimen [27]. This result is in accordance to another research by Bois et al. that stated how combined paclitaxel and cisplatin chemotherapies will cause toxicity in thrombocyte, erythrocyte, leukocyte, neutrophil, and neutropenia [28]. Statistically, this is no more significance compared to combined paclitaxel and carboplatin. This result is also supported by the research of Kitagawa et al. who stated that paclitaxel carboplatin chemotherapy has a higher risk of thrombocytopenia compared to paclitaxel cisplatin. It recorded 31 of 126 patients suffering from thrombocytopenia for those with paclitaxel carboplatin and the record of 4 of 125 cervical cancer patients suffering from it for those with paclitaxel cisplatin [7]. The decrease of thrombocyte level is higher in patients who underwent paclitaxel carboplatin chemotherapy compared to those who underwent paclitaxel cisplatin chemotherapy. This is due to how carboplatin regimen chemotherapy results in higher toxic effect toward blood function [23]. Decreased thrombocyte level from the normal one will result in thrombocytopenia that might cause bleeding [29].

Toxicity monitoring toward leukocyte value was also carried in this research. The result showed that there was a higher decrease of leukocyte level in paclitaxel carboplatin group with $10.51 \pm 8.83 \times 10^{3} / \mu \mathrm{L}$ compared to paclitaxel cisplatin group with $5.47 \pm 5.49 \times 10^{3} / \mu \mathrm{L}$ with the value of ${ }^{*} p>0.05$ was 0.202 . This means that there was no meaningful decrease of leukocyte values in squamous cell cervical cancer patients from before chemotherapy I and after chemotherapy VI with either paclitaxel cisplatin regimen or paclitaxel carboplatin regimen. This decrease was a side effect of cisplatin regimen chemotherapy that will cause mild leukopenia [9]. This decrease was also the side effect of carboplatin intake since its side effect includes myelosuppression or spinal cord depression that might lead to low blood cells production [30]. Cisplatin intake for 4 until 6 cycles of chemotherapies in cervical cancer patients will cause leukopenia with the percentage of $32.4 \%$ [18]. According to research by Umayahara et al., paclitaxel cisplatin regimen intake would cause Grade 3 leukopenia in 35 patients (51.47\%) of 68 cervical cancer patients [19]. On the other hand, paclitaxel carboplatin regimen intake would also cause leukopenia with the percentage of $13.8 \%$ in cervical cancer patients who underwent 6 cycles of chemotherapies [31]. The higher decrease of leukocyte values from paclitaxel carboplatin group in this research is in accordance to the research by Joseph et al. that stated paclitaxel carboplatin regimen intake was proven to be able in causing leukopenia with the percentage of $85 \%$ [26]. This result is also supported by the research of Ozols et al. that showed paclitaxel carboplatin regimen intake would cause 53\% patients to suffer from leukopenia compared to $51 \%$ for those with paclitaxel cisplatin intake in ovarium cancer patients [32]. The higher decrease of leukocyte level in paclitaxel carboplatin group compared to paclitaxel cisplatin group 
was due to how carboplatin has higher toxicity effect toward blood function. The effect was leukopenia that occurred after 14 days of the medicine intake [33]. The decrease of leukocyte level can increase the risk of infection because cervical cancer patients have immunity problems [2].

\section{CONCLUSION}

There was a decrease in hemoglobin, thrombocyte, and leukocyte level in patients who underwent both paclitaxel cisplatin and paclitaxel carboplatin chemotherapies. The decrease of hemoglobin level from patients in both regimen groups was not meaningful with the value of ${ }^{*} \mathrm{p}>0.05\left({ }^{*} \mathrm{p}=0.999\right)$. The decrease of thrombocyte level from patients in both regimen groups was meaningful with the value of *p $<0.05$ $\left({ }^{*} \mathrm{p}=0.022\right)$ in which patients who underwent paclitaxel carboplatin chemotherapy experienced from higher decrease. The decrease of leukocyte level was meaningful for patients in both regimen groups with the value of ${ }^{*} \mathrm{p}>0.05\left({ }^{*} \mathrm{p}=0.202\right)$ in which patients who underwent paclitaxel carboplatin chemotherapy experienced from higher decrease.

\section{ACKNOWLEDGMENT}

The authors would like to thank Prof. Dr. Ketut Suwiyoga, Sp.OG (K) as the Head of Specialist Doctor I Obstetric and Gynecology Study at UNUD Medicine Faculty/Sanglah Hospital, Denpasar, along with all the staffs at Sanglah Hospital Obstetric Polyclinic, Denpasar, for all of their assistance and cooperation.

\section{REFERENCES}

1. Kemenkes RI. (Kementrian Kesehatan Republik Indonesia). Pusat Data dan Informasi Kementrian Kesehatan RI. Jakarta: Kementerian Kesehatan Republik Indonesia; 2015a.

2. Kemenkes RI. Panduan Pelayanan Klinis Kanker Serviks. Jakarta: Kementerian Kesehatan Republik Indonesia; 2015b.

3. Skeel RT, Khleif SN. Handbook of Cancer Chemotherapy. $8^{\text {th }}$ ed. Philladelphia, PA: Lippincot William and Wilkins, A Wolters Kluwer Business; 2011. p. 118-25.

4. Komite Medik RSUP Sanglah. Protokol Kemoterapi Onkologi Ginekologi. Denpasar: Rumah Sakit Umum Pusat Sanglah; 2011.

5. Moore DH, Blessing JA, McQuellon RP, Thaler HT, Cella D, Benda J, et al. Phase III study of cisplatin with or without paclitaxel in stage IVB, recurrent, or persistent squamous cell carcinoma of the cervix: A gynecologic oncology group study. J Clin Oncol 2004;22:3113-9.

6. Hoskins WJ, Perez CA, Young RC. Principles and Practice of Gynecologic Oncology. $4^{\text {th }}$ ed. Philadelphia, PA: Lippincott Williams and Wilkins; 2005.

7. Kitagawa R, Katsumata N, Shibata T, Kamura T, Kasamatsu T, Nakanishi T, et al. Paclitaxel plus carboplatin versus paclitaxel plus cisplatin in metastatic or recurrent cervical cancer: The open-label randomized Phase III Trial JCOG0505. J Clin Oncol 2015;33:2129-35.

8. Andrijono AF, Saiffudin AB. Buku Acuan Nasional Onkologi Ginekologi. Jakarta: Yayasan Bina Pustaka Sarwono Prawirohardjo; 2006.

9. Anderson PO, Knoben JE, Troutman WG. Handbook of Clinical Drug Data. $10^{\text {th }}$ ed. USA: McGraw-Hill Companies, Inc; 2002.

10. Smith IE, O'Brien ME, Talbot DC, Nicolson MC, Mansi JL, Hickish TF, et al. Duration of chemotherapy in advanced non-small-cell lung cancer: A randomized trial of three versus six courses of mitomycin, vinblastine, and cisplatin. J Clin Oncol 2001;19:1336-43.

11. Herfindal ET, Gourley DR. Textbook of Therapeutics Drugs and Disease Management. USA: Lippincott Williams \& Wilkins; 2000.

12. WHO (World Health Organization). Comprehensive Cervical Cancer Control A Guide to Essential Practice. Switzerland: World Health Organization; 2014.

13. Lasut E, Rarung M, Suparman E. Karakteristik penderita kanker serviks di BLU RSUP Prof. Dr. R. D. Kandou. J e-Clin 2015;3:83-6. Available from:https://www.ejournal.unsrat.ac.id/index.php/eclinic/article/ view/6519.

14. Dandal A, Abajy MY, Alkhalaf M, Ibrahim A. Prevalence of human papilloma virus Types 16 And 18 among women with cervical cancer in aleppo, Syria. Int J Pharm Sci 2017;9:90-3. Available from: https://www.innovareacademics.in/journals/index.php/ijpps/article/ view/18773/12125

15. Pandey D, Shetty J, Sambhaji C, Saxena PU, Mishra D, Chawla A. Cervical Cancer as a silent killer: A rare case report with review of literature. J Cancer Res Ther 2015;11:653.

16. Antony A, Joel JJ, Shetty J, Umar NF. Identification and analysis of adverse drug reactions associated with cancer chemotherapy in hospitalized patients. Int J Pharm Sci 2016;8:448-51. Available from: http://www.innovareacademics.in/journals/index.php/ijpps/article/ view/11601/6208

17. Park DC, Kim JH, Lew YO, Kim DH, Namkoong SE. Phase II trial of neoadjuvant paclitaxel and cisplatin in uterine cervical cancer. Gynecol Oncol 2004:92:59-63.

18. Mell LK, Kochanski JD, Roeske JC, Haslam JJ, Mehta N, Yamada SD, et al. Dosimetric predictors of acute hematologic toxicity in cervical cancer patients treated with concurrent cisplatin and intensity-modulated pelvic radiotherapy. Int J Radiat Oncol Biol Phys 2006;66:1356-65.

19. Umayahara K, Takekuma M, Hirashima Y, Noda SE, Ohno T, Miyagi E, et al. Phase II study of concurrent chemoradiotherapy with weekly cisplatin and paclitaxel in patients with locally advanced uterine cervical cancer: The JACCRO GY-01 trial. Gynecol Oncol 2016;140:253-8.

20. Rodgers GM. Managing patients with chemotherapy-induce anemia. Adv Stud Med 2008;8:346-51. Available from: http://www.qu.edu. qa//2B Chemotherapy-Induced Anemia.pdf.

21. El-Deen DS, Al-Shahat M, El-Metwaly AE. Weekly paclitaxel and carboplatin for patients with advanced ovarian cancer. Med J Cairo Univ 2012;8025-31. Available from http//www.erepository.cu.edu.eg/ index.php/MJCU/article/view/977/954.

22. Handayani W, Haribowo AS. Buku Ajar Asuhan Keperawatan pada Klien dengan Gangguan Sistem Hematologi. Jakarta: Salemba Medika; 2008.

23. DiPiro JT, Talbert RL, Yee GC, Matzke GR, Wells BG, Posey LM. Pharmacotherapy: A Pathophysiologic Approach. $5^{\text {th }}$ ed. United States of America: The McGraw-Hill Companies, Inc; 2002.

24. Kee JL, Hayes ER. Farmakologi: Pendekatan Proses Keperawatan. Jakarta: Penerbit Buku Kedokteran EGC; 1994

25. Dollery C. Therapeutic Drugs. $2^{\text {nd }}$ ed. United Kingdom: Churchill Livingstone; 1999.

26. Joseph S, Pradeep S, Jayakumar KL. A prospective comparative study of the toxicity profile in patients receiving cisplatin-paclitaxel vs carboplatin-paclitaxel in advanced ovarian cancer. Int J Med Pharm Sci 2015;6:1-5. Available from: http://www.scopemed.org/?mno=205116.

27. Rosell R, Gatzemeier U, Betticher DC, Keppler U, Macha HN, Pirker R, et al. Phase III randomised trial comparing paclitaxel/carboplatin with paclitaxel/cisplatin in patients with advanced non-small-cell lung cancer: A cooperative multinational trial. Ann Oncol 2002;13:1539-49.

28. du Bois A, Lück HJ, Meier W, Adams HP, Möbus V, Costa S, et al. A randomized clinical trial of cisplatin/paclitaxel versus carboplatin/ paclitaxel as first-line treatment of ovarian cancer. J Natl Cancer Inst 2003;95:1320-9

29. Gibson J. Fisiologi dan Anatomi Modern untuk Perawat. Jakarta: ECG; 2003.

30. Sweetman SC. Martindale: The Complete Drug Reference. $36^{\text {th }}$ ed. London: Pharmaceutical Press; 2009.

31. Panichevaluk A. Phase II study of paclitaxel plus carboplatin in recurrent and/or metastatic cervical carcinoma. Thai J Obstet Gynaecol 2003;15:33-7. Available from: http:/www.tci-thaijo.org/index.php/ tjog/article/view/82779.

32. Ozols RF, Bundy BN, Greer BE, Fowler JM, Clarke-Pearson D, Burger RA, et al. Phase III trial of carboplatin and paclitaxel compared with cisplatin and paclitaxel in patients with optimally resected stage III ovarian cancer: A Gynecologic Oncology Group study. J Clin Oncol 2003;21:3194-200

33. Cassidy J, Bissett D, Obe RA. Oxford Handbook of Oncology. New York: Oxford University Press; 2002. 